\title{
Evaluation of Cytotoxicity, Total Phenolic Content and Antioxidant Innate Reveal Efficient Medications in Native Lactuca indica
}

\author{
Jeong-Hun Park ${ }^{1, \dagger}$, Jeoung-Hwa Shin ${ }^{2, \dagger}$, Swapan Kumar Roy ${ }^{3} \&$ Hyeon-Yong Park ${ }^{1}$ \\ ${ }^{1}$ Department of Life Science, College of Natural Science, Chosun University, Gwangju, Korea \\ ${ }^{2}$ Seoul Center, Korea Basic Science Institute, Seoul, Korea \\ ${ }^{3}$ Department of Crop Science, Chungbuk National University, Cheongju, Korea \\ Correspondence: Hyeon-Yong Park, Department of Life Science, College of Natural Science, Chosun University, \\ Gwangju 500-712, Korea. Tel: 82-62-230-6652. E-mail: hypark@chosun.ac.kr \\ ${ }^{\dagger}$ These authors are equally contributed to this work.
}

Received: June 25, 2014 Accepted: August 5, 2014 Online Published: September 15, 2014

doi:10.5539/jas.v6n10p135 URL: http://dx.doi.org/10.5539/jas.v6n10p135

\begin{abstract}
Lactuca indica is an edible wild vegetable, which is frequently availed as a folk remedy for its anti-inflammatory, antibacterial, and other treatments in Asia. This study was executed to evaluate the cytotoxicity, antioxidant and phenolic contents of the methanol extracts from different organs of Lactuca indica. The highest amount of phenolics found in the methanol extracts of leaf $(35.09 \pm 0.15 \mathrm{mg} / \mathrm{g})$, followed by stem $(15.44 \pm 0.20 \mathrm{mg} / \mathrm{g})$, root $(13.50 \pm 0.19 \mathrm{mg} / \mathrm{g})$ and flower $(12.50 \pm 0.39 \mathrm{mg} / \mathrm{g})$ while the highest flavonoid contents also observed in the methanol extracts of leaf $(26.90 \pm 0.22 \mathrm{mg} / \mathrm{g})$. Methanol extracts of leaf showed a pronounced DPPH radical scavenging activity $(90.37 \pm 0.15 \mathrm{mg} / \mathrm{mL})$ and the ABTS radical scavenging activity $(99.84 \pm 0.02 \mathrm{mg} / \mathrm{mL})$ at 10 $\mathrm{mg} / \mathrm{mL}$ and $20 \mathrm{mg} / \mathrm{mL}$ respectively. Using MTT assay, the methanol extracts of leaf showed the highest cytotoxicity $\left(\mathrm{IC}_{50} 113.84 \mu \mathrm{g} / \mathrm{mL}\right.$ ) against human breast adenocarcinoma cell (MCF-7). To this end, the results revealed that the phenolic contents were highly correlated with the DPPH and ABTS radical scavenging activity. The findings suggest that it could contribute to the antioxidant properties of different organs of the studied plant. In this regard, the cytotoxicity and antioxidant properties could be helpful for the evaluation of the bioactive properties of Lactuca indica.
\end{abstract}

Keywords: cytotoxicity, total polyphenols, methanol extracts, antioxidant activity, Lactuca indica

\section{Introduction}

Lactuca indica, a biennial flowering plant belonging to the family Compositae, is widely distributed in East Asia. The leaves and roots of $L$. indica have a unique taste and flavor, and have been massively used as a traditional oriental medicine and food. Lactuca indica is well known for the treatment of various pharmacological effects for human health. It has also anti-inflammatory and antibacterial activities. Furthermore, in several medications, the whole plant part of Lactuca indica has been given orally or topically prescribed in order to mitigate intestinal disorders (Wang et al., 2003).

Some plants enable cytotoxic properties and the effectiveness of the plant products is correlated for its bioactive compounds, especially antioxidant phenolics. Phenolics, the antioxidant compounds exhibited many essential properties like hypocholesterolemic, hypolipidemic, anti-hypertensive, antidiabetic, anti-thrombotic and anti-hyperhomocystic and so on (Chon et al., 2009).

Recently, plant and plant-derived products are treated as an essential part of the health care system by applying the bioactive phytochemicals. As a health-protecting factor, the compounds, antioxidants act a crucial role in food. In a typical diet, most of the antioxidant compounds are originated from plant sources and it includes various classes of compounds with a wide range of physical and chemical characteristics (Shah et al., 2010). The main characteristic of an antioxidant is its ability to eliminate free radicals. In biological systems, the highly reactive free radicals and oxygen species are avaiable from a wide variety of sources. Plant contains many antioxidant enzymes such as superoxide dismutase (SOD), catalase (CAT), peroxidase (POD), and ascorbate 
peroxidase (APX) against ROS (reactive oxygen species) (Zhou et al., 2005). However, when the plants are subjugated to adverse conditions, the production of activated oxygen species appears significantly (Dionisio-Sese \& Tobita, 1998). In plants, both the enzymatic and nonenzymatic antioxidant process is available and eventually, superoxide radicals are detoxified by SOD and hydrogen peroxide is annihilated by CAT and various types of peroxidases (Kang \& Saltveit, 2002).

The phenolic constituents revealed in vegetables have accelerated notable attention for existing the key components of antioxidant activity (Cartea et al., 2010). The antioxidant activity of phenolic constituents has been imposed for its oxide-reduction properties that act a crucial role in the adsorption or neutralization of free radicals (Basile et al., 2005).

Furthermore, hydrogen peroxide-detoxifying system is the ascorbate-glutathione cycle that involves APX and glutathione reductase (GR) in plant (Asada et al., 1994). It is now widely recognized that reactive oxygen species (ROS) are subjected various stress-induced injury to macromolecules and consequently to cellular structure (Kandpal et al., 1981; Moftah \& Michel, 1987), which needs to be scavenged for the maintenance of normal growth. In various parts of plant cells, ascorbate peroxidase, catalase and peroxidase, along with some low-molecular weight scavengers such as ascorbate, glutathione and proline, play active defense role against ROS production (Apel \& Hirt, 2004). Under various stress conditions, the presence of ROS-scavenging enzymes, such as SOD, POXs and CAT, is the prominent mechanism for detoxifying ROS synthesization (Mittler, 2002; Wojtaszek, 1997).

Measurement of cell viability and proliferation is thought to be one of the most essential issues for different kind of invitro assays of a cell population's response to external factors. The reduction of tetrazolium salts is now extensively recogniged as a potential way to investigate cell proliferation (Chon et al., 2009). It is important thing that should consider that the assays condition can change the metabolic activity and eventually in the cytosolic compartment of the cell, tetrazolium dye reduction is largely dependent on the NAD $(\mathrm{P}) \mathrm{H}$-dependent oxidoreductase enzymes (Berridge et al., 2005).

In this context, the present study was conducted to evaluate the content of total phenolics, antioxidant activity and the effects of cytotoxicity in the various parts of their methanol extracts in the widely medicated medicinal plants, Lactuca indica.

\section{Materials and Methods}

\subsection{Plant Material and Extract Preparation}

The roots, stems, leaves and flowers of Lactuca indica were collected from Jonjae Mountain in Boseong, Korea. The samples were directly freeze-dried and then ground into a fine powder. The sample was stored at $-20^{\circ} \mathrm{C}$ for investigation. Methanol extracts were prepared by soaking the sample powder into $100 \%$ methanol for 24 hours at room temperature. The crude extracts were filtered through a Whatman filter paper No. 3. The collected filtrate was evaporated to dryness under vacuum at $-45^{\circ} \mathrm{C}$ using a rotary evaporator (IKA RV 10, Germany). The concentrated methanol extract was stored at $-20^{\circ} \mathrm{C}$ until further required.

\subsection{Measurement of Cytotoxicity by MTT Assay}

The cytotoxicity of each plant sample was assayed using human cancer cell lines, HeLa for human metrocarcinoma, Calu-6 for human pulmonary carcinoma, MCF-7 for human breast adenocarcinoma, HCT-116 for human colorectal carcinoma, SNU-1066 for human laryngeal squamous cell carcinoma and a normal cell line HEK-293 for human embryonic kidney as previously described (Hansen et al., 1989). The cell lines were purchased from Korea Cell Line Bank (KCLB) for MTT (3-(4,5-dimethylthiazol-2-yl)-2,5-diphenyltetrazolium bromide) assay. The cells were plated on 96 well plates at a concentration of $3 \times 10^{4}$ cells $/ \mathrm{mL}$. The cells were incubated for $24 \mathrm{hrs}$ in RPMI- 1640 medium at $37{ }^{\circ} \mathrm{C}$ under $5 \% \mathrm{CO}_{2}$ in a humidified incubator, and treated with 2 $\mu \mathrm{L}$ of various concentrations $\left(50,100,200,400\right.$, and $\left.800 \mu \mathrm{g} \mathrm{mL}^{-1}\right)$ of extracts. After the incubation for $48 \mathrm{hr}$, the cells were washed twice with phosphate buffer solution (PBS). MTT solution at $5 \mathrm{mg} / \mathrm{mL}$ was dissolved in $1 \mathrm{~mL}$ of PBS, and $10 \mu \mathrm{L}$ of it was added to each of the 96 wells. After the reaction for $4 \mathrm{hr}$, the solution in each well containing media, unbound MTT and dead cells were removed by suction and $100 \mu \mathrm{L}$ of DMSO was added to each well. The plates were shaken for 15 minute by plate shaker, and the absorbance was recorded using a ELISA reader (Bio-Rad model 550, USA) at a wavelength of $540 \mathrm{~nm}$. The viability of the treatment was determined as percentage of viability compared to untreated cell, and the values were then used to iteratively calculate the concentration of plant extracts required to cause a $50 \%$ reduction $\left(\mathrm{IC}_{50}\right)$ in growth for each cell lines. 


\subsection{Determination of Total Phenol}

Total phenols were determined by the modified method of the Folin- Ciocalteu assay (Singleton \& Rossi, 1965). Freeze-dried samples were extracted with methanol, and then the extract was concentrated under reduced pressure, and freeze-dried in powder. Freeze-dried powder $(1 \mathrm{mg})$ dissolved in $95 \%$ methanol, and $500 \mu \mathrm{L}$ of Folin-Ciocalteu reagent were added to a $25 \mathrm{~mL}$ volumetric flask, and mixed for 5 minute at $30{ }^{\circ} \mathrm{C}$ in water bath. Saturated solution $(500 \mu \mathrm{L})$ of $7.5 \% \mathrm{Na}_{2} \mathrm{CO}_{3}$ was added to the mixture followed by incubating for $1 \mathrm{hr}$ at room temperature, and the absorbance was read at $725 \mathrm{~nm}$ using a spectrophotometer (Biochrom Co., England). Total phenolic of the sample was expressed as mg chlorogenic acid equivalent in $1 \mathrm{~g}$ dry weight of sample extract.

\subsection{Total Flavonoid Determination}

Total flavonoid was measured using the modified method that previously described (Zhishen et al., 1999). Briefly, freeze-dried samples $(1 \mathrm{mg}$ ) dissolved in $95 \%$ methanol, and $1 \mathrm{~mL}$ of extract solution, $10 \mathrm{~mL}$ diethylene glycol and $0.1 \mathrm{~mL} 1 \mathrm{~N} \mathrm{NaOH}$ were added to a $25 \mathrm{~mL}$ volumetric flask. The mixture was incubated for $1 \mathrm{hr}$ at $37{ }^{\circ} \mathrm{C}$ in water bath. The absorbance was measured at $420 \mathrm{~nm}$ using a spectrophotometer (Biochrom Co., England). Total flavonoid of the samples was expressed as $\mathrm{mg}$ narincin equivalent in $1 \mathrm{~g}$ dry weight of sample extract.

\subsection{Assay of Antioxidant Enzyme}

\subsubsection{SOD Activity}

The superoxide dismutase (SOD) activity was measured using SOD assay Kit-WST, purchased from Sigma-Aldrich (Sigma-Aldrich Co., Japan). This assay is based on the colorimetric assay for the measurement of total antioxidant capacity of crude aqueous fractions. The $60 \mu \mathrm{L}$ of sample solution (sample and blank 2) or doubledistilled water (blank 1 and blank 3) was mixed with $600 \mu \mathrm{L}$ of WST working solution. For blank 2 and blank 3, $60 \mu \mathrm{L}$ of dilution buffer was added. Then, $60 \mu \mathrm{L}$ of enzyme working solution was added to each sample and blank 1 . The plate was incubated at $37^{\circ} \mathrm{C}$ for $20 \mathrm{~min}$, and the OD value (Optical density) was determined at $450 \mathrm{~nm}$ using a spectrophotometer (Biochrom Co., England). SOD activity (inhibition rate percent) was calculated using the following equation:

$$
\text { SOD activity }=\{[(\text { Ablank1 }- \text { Ablank3 })-(\text { Asample }- \text { Ablank2) }] /(\text { Ablank } 1-\text { Ablank } 3)\} \times 100
$$

\subsubsection{CAT Activity}

Catalase (CAT) activity was assayed by the method which was previously described (Mishra et al., 1993). The reaction mixture composed of $50 \mathrm{mM}$ potassium phosphate buffer $\left(\mathrm{pH} \mathrm{7.0)}, 11 \mathrm{mM} \mathrm{H}_{2} \mathrm{O}_{2}\right.$, and the crude enzyme extract. The reaction was initiated by the addition of $\mathrm{H}_{2} \mathrm{O}_{2}$ to the mixture, and enzyme activity was determined by monitoring the decline in absorbance at $240 \mathrm{~nm}\left(\varepsilon=36 \mathrm{M}^{-1} \mathrm{~cm}^{-1}\right)$, because of $\mathrm{H}_{2} \mathrm{O}_{2}$ consumption.

\subsubsection{APX Activity}

Ascorbate peroxidase (APX) activity was determined by monitoring the decline of absorbance at $290 \mathrm{~nm}$ as ascorbate $\left(\varepsilon=2.8 \mathrm{mM}^{-1} \mathrm{~cm}^{-1}\right)$ was oxidized, by the method that previously described (Chen \& Asada, 1989). The reaction mixture composed of $100 \mathrm{mM}$ potassium phosphate buffer $(\mathrm{pH} 7.5), 0.5 \mathrm{mM}$ ascorbate, and 0.2 $\mathrm{mM} \mathrm{H}_{2} \mathrm{O}_{2}$.

\subsubsection{POX Activity}

Peroxidase (POX) activity was determined specifically with guaiacol at $470 \mathrm{~nm}\left(\varepsilon=26.6 \mathrm{mM}^{-1} \mathrm{~cm}^{-1}\right)$, following the method which was previously described (Egley et al., 1983). The reaction mixture contained $40 \mathrm{mM}$ potassium phosphate buffer ( $\mathrm{pH} 6.9), 1.5 \mathrm{mM}$ guaiacol, and $6.5 \mathrm{mM} \mathrm{H}_{2} \mathrm{O}_{2}$ in $1 \mathrm{ml}$ with crude enzyme extract. Control assays were performed in which the enzyme extracts or substrates were replaced by buffer.

\subsection{DPPH Radical Scavenging Assay}

The antioxidant activity assay of each extract was performed by the measuring of the electron donor capacity of DPPH. $100 \mu \mathrm{L}$ of various concentrations $\left(100,250,500,1000,2500,5000\right.$ and $\left.10000 \mathrm{mg} \mathrm{L}^{-1}\right)$ of extracts of Lactuca indica were added to $900 \mu \mathrm{L}$ of $100 \%$ methanol containing $100 \mu \mathrm{M} \mathrm{DPPH}$, and the reaction mixture was shaken for $5 \mathrm{~min}$ in the slight vortex. Leaving the samples at room temperature for $30 \mathrm{~min}$ under darkness, and the absorbance of DPPH was determined by spectrophotometer at $517 \mathrm{~nm}$. The DPPH radical scavenging activity was calculated according to the following equation:

$$
\text { Scavenging effect on DPPH radical }(\%)=[(\mathrm{A}-\mathrm{B}) / \mathrm{A}] \times 100
$$

Where $\mathrm{A}$ is the absorbance at $517 \mathrm{~nm}$ without pigment compositions and $\mathrm{B}$ is the change in absorbance at 517 $\mathrm{nm}$ with pigment compositions incubation (Brand-Williams et al., 1995). 


\subsection{Nitrite Scavenging Assay}

The nitrite scavenging activity (NSA) was determined according to a method using Griess reagent (Kato et al., 1987). First, $40 \mu \mathrm{L}$ of each sample was mixed with $20 \mu \mathrm{L}$ of $1 \mathrm{mM}$ nitrite sodium. Then the mixture was added to $140 \mu \mathrm{L}$ of $0.2 \mathrm{M}$ citrate buffer ( $\mathrm{pH} 3.0,4.2$, or 6.0 ). The final volume of each sample was adjusted to $200 \mu \mathrm{L}$. After the mixtures were incubated for $1 \mathrm{~h}$ at $37^{\circ} \mathrm{C}$, and added to $1000 \mu \mathrm{L}$ of $2 \%$ acetic acid and $80 \mu \mathrm{L}$ of Griess reagent ( $1 \%$ sulfanilic acid and $1 \%$ naphthylamine in a methanol solution containing $30 \%$ acetic acid). After vigorous mixing with a vortex, the mixture was placed at room temperature for $15 \mathrm{~min}$, and absorbance was measured at $520 \mathrm{~nm}$. The nitrite scavenging activity was determined based on the following formula:

$$
\text { NSA }(\%)=((1-A-C) / B) \times 100
$$

Where $\mathrm{A}$ is the absorbance of the mixture sample during a reation with $1 \mathrm{mM} \mathrm{NaNO}_{2}$ after a $1 \mathrm{~h}$ reaction, $\mathrm{B}$ is the absorbance of a mixture of distilled water and $1 \mathrm{mM} \mathrm{NaNO}_{2}$ after a $1 \mathrm{~h}$ reaction and $\mathrm{C}$ is the absorbance of the sample.

\subsection{ABTS Radical Scavenging Assay}

The spectrophotomeric analysis of ABTS (2,2'-azinbis-(3-ethyl-benzothiazoline-6-sulfonic acid) radical cation $\left(\mathrm{ABTS}^{+}\right.$) scavenging activity of Lactuca indica was determined according to the method described previously (Re et al., 1999). ABTS solution $(7 \mathrm{mM})$ and potassium persulfate $(2.45 \mathrm{mM})$ were mixed, and the mixture was incubated in the dark at room temperature for $15 \mathrm{hrs}$, and then was diluted to the absorbance 0.7 at $734 \mathrm{~nm}$. 50 $\mu \mathrm{L}$ of each sample prepared in different concentrations with $950 \mu \mathrm{L}$ diluted solution was added, and was shaken for 10 seconds by vortex mixer, and then reacted for $5 \mathrm{~min}$ at room temperature, and the absorbance was read at $734 \mathrm{~nm}$ using a spectrophotometer (Biochrom Co., England). The $\mathrm{ABTS}^{+}$scavenging activity showed as RAEAC (relative ascorbic acid equivalent antioxidant capacity), was calculated by the following equation:

$$
\mathrm{RAEAC}=\frac{\mathrm{Caa}}{\Delta \mathrm{Aaa}} \times \frac{\Delta \mathrm{As}}{\mathrm{Cs}}
$$

Where

$\triangle$ Aaa: change of the absorbance after addition of ascorbic acid;

Caa: concentration of ascorbic acid;

$\Delta$ As: change of the absorbance after addition of sample solution;

Cs: concentration of sample.

\subsection{Data Analysis}

All experiments were conducted for three to five independent replicates. The data are expressed in terms of mean and standard error. The statistical analysis was performed using the procedures of the Statistical Analysis System (SAS version 9.1). ANOVA procedure followed by Duncan Multiple Range Test was used to determine the significant difference at the $P<0.05$ level.

\section{Results}

\subsection{Cytotoxicity}

The cytotoxicity of Lactuca indica on five human cancer cell lines and a normal cell line was evaluated by using the MTT assay. When cells were treated for $48 \mathrm{hrs}$ with various concentrations $(50,100,200,400$ and 800 $\mu \mathrm{g} / \mathrm{mL}$ ) of methanol extracts, the rate of cell survival progressively decreased in a dose-dependent manner. Methanol extracts at $50 \mu \mathrm{g} / \mathrm{mL}$ from roots exhibited a pronounced cytotoxic effect (117.74\%) on HEK 293 cell comparable to that of methanol extract from stem (58.51\%) on SNU-1066 cell at the same concentration. In root extract, the values of $\mathrm{IC}_{50}$ (concentration causing $50 \%$ cell death) showed the highest activity against MCF-7 $(113.84 \mu \mathrm{g} / \mathrm{mL})$ whereas all extracts on HEK 293 exhibited the weakest inhibition on cell viability, having an $\mathrm{IC}_{50}$ value of over $800 \mu \mathrm{g} / \mathrm{mL}$. However, methanol extracts from leaf showed the highest activity against HeLa $\left(\mathrm{IC}_{50}\right.$ of $\left.266.28 \mu \mathrm{g} / \mathrm{mL}\right)$, followed by stem $(308.27 \mu \mathrm{g} / \mathrm{mL})$, root $(535.81 \mu \mathrm{g} / \mathrm{mL})$ and flower $(>800 \mu \mathrm{g} / \mathrm{mL})$. In addition, the methanol extracts from stem showed the highest activity against Calu- $6\left(\mathrm{IC}_{50}\right.$ of $\left.689.76 \mu \mathrm{g} / \mathrm{mL}\right)$, followed by stem $(311.90 \mu \mathrm{g} / \mathrm{mL})$, $\operatorname{root}(>800 \mu \mathrm{g} / \mathrm{mL})$ and flower $(>800 \mu \mathrm{g} / \mathrm{mL})$. 
Table 1. Cytotoxicity of extracts from the different organs of Lactuca indica on five human cancer cell lines and a normal cell line HEK-293

\begin{tabular}{|c|c|c|c|c|c|c|c|}
\hline \multirow{3}{*}{ Cell line } & \multirow{3}{*}{ Plant organ } & \multicolumn{6}{|c|}{ Cell viability ( $\%$ of control) } \\
\hline & & \multicolumn{6}{|c|}{ Concentration $(\mu \mathrm{g} / \mathrm{mL})$} \\
\hline & & 50 & 100 & 200 & 400 & 800 & IC50 \\
\hline \multirow{4}{*}{$\mathrm{HeLa}$} & Root & $71.90 \pm 6.11 \mathrm{a}$ & $74.53 \pm 8.29 \mathrm{a}$ & $50.82 \pm 1.52 b$ & $52.00 \pm 0.27 \mathrm{~b}$ & $43.36 \pm 1.91 b$ & 535.81 \\
\hline & Stem & $67.17 \pm 5.11 \mathrm{a}$ & $53.82 \pm 7.65 \mathrm{a}$ & $49.36 \pm 1.74 b$ & $41.90 \pm 4.50 \mathrm{c}$ & $37.51 \pm 0.64 b c$ & 308.27 \\
\hline & Leaf & $61.45 \pm 5.98 \mathrm{a}$ & $58.50 \pm 4.73 a$ & $45.78 \pm 4.25 b$ & $44.00 \pm 2.76 b c$ & $32.30 \pm 4.63 \mathrm{c}$ & 266.28 \\
\hline & Flower & $78.22 \pm 9.48 \mathrm{a}$ & $68.34 \pm 4.41 \mathrm{a}$ & $69.39 \pm 3.18 \mathrm{a}$ & $66.48 \pm 2.11 \mathrm{a}$ & $67.21 \pm 1.72 \mathrm{a}$ & $>800$ \\
\hline \multirow{4}{*}{ Calu-6 } & Root & $61.85 \pm 2.57 \mathrm{c}$ & $60.20 \pm 2.92 c$ & $63.08 \pm 4.90 \mathrm{~b}$ & $51.48 \pm 0.87 \mathrm{~b}$ & $51.27 \pm 5.85 \mathrm{a}$ & $>800$ \\
\hline & Stem & $79.60 \pm 4.53 \mathrm{a}$ & $74.53 \pm 1.35 \mathrm{ab}$ & $71.05 \pm 2.27 \mathrm{ab}$ & $71.37 \pm 1.35 \mathrm{a}$ & $41.70 \pm 5.17 \mathrm{a}$ & 689.76 \\
\hline & Leaf & $69.01 \pm 2.01 \mathrm{bc}$ & $70.44 \pm 2.38 b$ & $67.05 \pm 3.89 b$ & $47.95 \pm 5.10 \mathrm{~b}$ & $45.54 \pm 0.61 \mathrm{a}$ & 311.90 \\
\hline & Flower & $77.38 \pm 3.05 \mathrm{ab}$ & $81.27 \pm 4.01 \mathrm{a}$ & $81.87 \pm 4.76 \mathrm{a}$ & $66.00 \pm 3.34 \mathrm{a}$ & $57.95 \pm 8.12 \mathrm{a}$ & $>800$ \\
\hline \multirow{4}{*}{ MCF-7 } & Root & $64.52 \pm 4.17 b$ & $44.08 \pm 1.30 \mathrm{~b}$ & $41.67 \pm 2.37 \mathrm{a}$ & $37.64 \pm 0.52 \mathrm{a}$ & $31.33 \pm 2.79 \mathrm{a}$ & 113.84 \\
\hline & Stem & $71.34 \pm 1.94 \mathrm{ab}$ & $46.66 \pm 3.09 \mathrm{ab}$ & $45.27 \pm 5.47 \mathrm{a}$ & $38.91 \pm 4.68 \mathrm{a}$ & $29.98 \pm 3.59 \mathrm{ab}$ & 150.03 \\
\hline & Leaf & $78.00 \pm 4.49 \mathrm{a}$ & $62.61 \pm 10.61 \mathrm{a}$ & $45.61 \pm 7.45 \mathrm{a}$ & $34.18 \pm 4.59 \mathrm{a}$ & $23.23 \pm 1.66 b$ & 173.22 \\
\hline & Flower & $64.17 \pm 3.11 b$ & $44.29 \pm 2.30 \mathrm{ab}$ & $42.67 \pm 1.30 \mathrm{a}$ & $43.12 \pm 2.14 \mathrm{a}$ & $32.09 \pm 1.04 \mathrm{a}$ & 128.56 \\
\hline \multirow{4}{*}{ HCT-116 } & Root & $91.32 \pm 7.68 \mathrm{a}$ & $84.66 \pm 7.07 \mathrm{~b}$ & $87.31 \pm 6.37 \mathrm{a}$ & $87.39 \pm 2.99 a$ & $76.64 \pm 2.77 \mathrm{a}$ & $>800$ \\
\hline & Stem & $66.88 \pm 6.78 b$ & $100.60 \pm 2.65 \mathrm{a}$ & $63.71 \pm 1.49 b$ & $88.48 \pm 9.64 \mathrm{a}$ & $79.93 \pm 9.47 \mathrm{a}$ & $>800$ \\
\hline & Leaf & $77.26 \pm 4.58 \mathrm{ab}$ & $64.44 \pm 2.63 c$ & $67.57 \pm 8.00 \mathrm{~b}$ & $83.32 \pm 6.26 \mathrm{a}$ & $86.20 \pm 3.12 \mathrm{a}$ & $>800$ \\
\hline & Flower & $70.77 \pm 1.92 b$ & $85.26 \pm 0.71 b$ & $81.87 \pm 4.41 \mathrm{ab}$ & $68.86 \pm 4.11 \mathrm{a}$ & $79.98 \pm 5.36 \mathrm{a}$ & $>800$ \\
\hline \multirow{4}{*}{ SNU-1066 } & Root & $79.22 \pm 2.50 \mathrm{~b}$ & $62.27 \pm 3.28 b$ & $59.53 \pm 3.44 b$ & $56.94 \pm 0.56 b$ & $41.26 \pm 1.77 b$ & 556.02 \\
\hline & Stem & $58.51 \pm 2.83 \mathrm{c}$ & $56.29 \pm 3.73 b$ & $53.68 \pm 1.27 b$ & $47.52 \pm 1.35 \mathrm{c}$ & $46.42 \pm 1.68 b$ & $>800$ \\
\hline & Leaf & $90.32 \pm 1.03 \mathrm{a}$ & $86.83 \pm 7.60 \mathrm{a}$ & $88.50 \pm 8.90 \mathrm{a}$ & $96.81 \pm 2.87 \mathrm{a}$ & $84.80 \pm 4.64 \mathrm{a}$ & $>800$ \\
\hline & Flower & $64.51 \pm 3.14 \mathrm{c}$ & $64.75 \pm 2.99 b$ & $66.12 \pm 5.34 b$ & $63.49 \pm 3.71 b$ & $51.06 \pm 3.83 b$ & $>800$ \\
\hline \multirow{4}{*}{ HEK293 } & Root & $117.74 \pm 5.11 \mathrm{a}$ & $113.33 \pm 7.99 a$ & $111.45 \pm 7.95 \mathrm{a}$ & $99.43 \pm 8.22 \mathrm{a}$ & $106.46 \pm 7.44 a$ & $>800$ \\
\hline & Stem & $81.18 \pm 9.44 b$ & $94.60 \pm 3.99 \mathrm{ab}$ & $86.07 \pm 6.96 b$ & $87.45 \pm 1.93 \mathrm{ab}$ & $82.57 \pm 2.59 b$ & $>800$ \\
\hline & Leaf & $107.10 \pm 7.53 \mathrm{ab}$ & $114.61 \pm 8.49 \mathrm{a}$ & $97.34 \pm 7.06 \mathrm{ab}$ & $95.00 \pm 1.96 \mathrm{ab}$ & $93.95 \pm 0.87 \mathrm{ab}$ & $>800$ \\
\hline & Flower & $103.14 \pm 6.19 \mathrm{ab}$ & $87.04 \pm 3.76 b$ & $79.16 \pm 2.58 b$ & $80.98 \pm 4.48 b$ & $84.11 \pm 4.66 b$ & $>800$ \\
\hline
\end{tabular}

${ }_{\mathrm{z}}$ Data represent the mean values \pm SE of three independent experiments. Means with the same letter in column are not significantly different at $\mathrm{p}<0.05$ level by Duncan's multiple range test.

HeLa: human metrocarcinoma cell, Calu-6: human pulmonary carcinomacell, MCF-7: human breast adenocarcinoma cell, HCT-116: human colorectal carcinoma cell, SNU-1066: human laryngeal squamous carcinoma cell, HEK-293: a normal cell for human embryonic kidney.

However, methanol extracts from root performed the highest activity against MCF-7 cell ( $\mathrm{IC}_{50}$ of $113.84 \mu \mathrm{g} / \mathrm{mL}$ ), followed by flower $(128.56 \mu \mathrm{g} / \mathrm{mL})$, stem $(150.03 \mu \mathrm{g} / \mathrm{mL})$ and leaf $(173.22 \mu \mathrm{g} / \mathrm{mL})$ respectively. However, the methanol extracts from all organs (root, stem, leaf and flower) showed the weakest inhibition $\left(\mathrm{IC}_{50}>800 \mu \mathrm{g} / \mathrm{mL}\right.$ ) on cell viability against HCT-116 and HEK 293 cell lines. Furthermore, the methanol extracts from stem, leaf 
and flower also showed weakest inhibition $\left(\mathrm{IC}_{50}>800 \mu \mathrm{g} / \mathrm{mL}\right)$ on cell viability against SNU-1066 except the extract from root $(556.02 \mu \mathrm{g} / \mathrm{mL})$ (Table 1).

\subsection{Total Polyphenol and Flavonoid Contents}

The highest total polyphenol content was observed from the methanol extract of leaf $(35.09 \pm 0.15 \mathrm{mg} / \mathrm{g})$, followed by stem $(15.44 \pm 0.20 \mathrm{mg} / \mathrm{g})$, $\operatorname{root}(13.50 \pm 0.19 \mathrm{mg} / \mathrm{g})$ and flower $(12.50 \pm 0.39 \mathrm{mg} / \mathrm{g})$. The differences were statistically significant $(\mathrm{P}<0.05)$. However, the highest flavonoid content $(26.90 \pm 0.22 \mathrm{mg} / \mathrm{g})$ was also found in the leaf of Lactuca indica and the lowest flavonoid content was found from the methanol extracts of $\operatorname{root}(1.43 \pm 0.14 \mathrm{mg} / \mathrm{g})$ whereas the flavonoid content from flower and stem were $(6.20 \pm 0.22 \mathrm{mg} / \mathrm{g})$ and $(5.34 \pm$ $0.13 \mathrm{mg} / \mathrm{g}$ ) respectively (Table 2 ).

Table 2. Total polyphenol and flavonoid contents of the different organs extracts in Lactuca indica

\begin{tabular}{ccc}
\hline Plant Organ & $\begin{array}{c}\text { Total Polyphenol } \\
(\mathbf{m g} / \mathbf{g} \text { Extract DW) }\end{array}$ & $\begin{array}{c}\text { Total Flavonoid } \\
(\mathbf{m g} / \mathbf{g} \text { Extract DW) }\end{array}$ \\
\hline Root & $13.50 \pm 0.19^{\mathrm{bc}}$ & $1.43 \pm 0.14^{\mathrm{d}}$ \\
Stem & $15.44 \pm 0.20^{\mathrm{b}}$ & $5.34 \pm 0.13^{\mathrm{c}}$ \\
Leaf & $35.09 \pm 0.15^{\mathrm{a}}$ & $26.90 \pm 0.22^{\mathrm{a}}$ \\
Flower & $12.50 \pm 0.39^{\mathrm{c}}$ & $6.20 \pm 0.22^{\mathrm{b}}$
\end{tabular}

${ }^{\mathrm{z}}$ Data represent the mean values $\pm \mathrm{SE}$ of three independent experiments. Means with the same letter in column are not significantly different at $\mathrm{p}<0.05$ level by Duncan's multiple range test.

\subsection{Antioxidant Enzyme Activity}

In order to investigate the antioxidant properties of Lactuca indica extract, superoxide dismutase (SOD), catalase (CAT), ascorbate peroxidase (APX) and peroxidase (POX) activities were measured. The highest SOD activity $(90 \%)$ was found from the methanol extracts of leaf and the lowest activity was observed from the root and flower extract $(85 \%)$ while in stem extract, SOD activity level $(89 \%)$ was increased than that of root and flower extracts (Figure 1). The CAT activity was occurred in a various organ extract dependent manner. However, in root extract, the CAT activity was increased significantly $\left(13 \mathrm{mmol}_{2} \mathrm{O}_{2}\right.$ decomposed $\mathrm{min} / 1 \mathrm{mg}$ protein) whereas no significance differences were revealed from the flower, leaf and stem extract. In the case of APX activity, there was no significance differences between the stem and flower extract while the highest activity was observed in the root extract $(660 \mathrm{mmol}$ ascorbate oxidized $/ \mathrm{min} / \mathrm{mg}$ protein) and the leaf extract showed the lowest activity. Furthermore, the highest POD activity was reveled in the extract of stem (7 umol tetraguiacol/min/mg protein), followed by flower, root and leaf extract (Figure 1). 


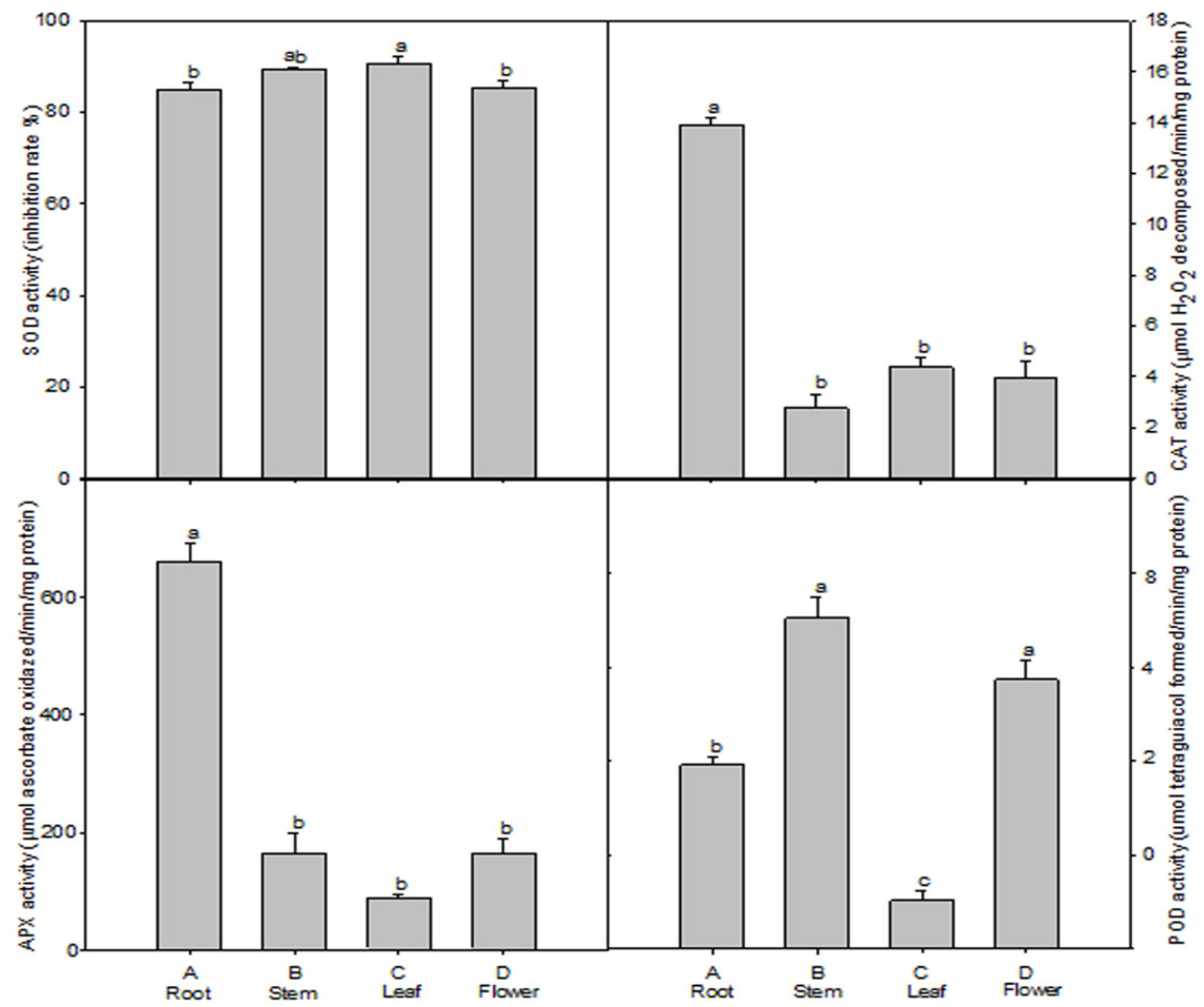

Figure 1. Antioxidant enzyme activities according to the different organs extracts in Lactuca indica

The results represent mean \pm SE of three independent experiments. Different letters indicate significantly different values.

\subsection{DPPH Radical Scavenging Activity}

DPPH assays were performed to evaluate the radical scavenging activities of Lactuca indica extracts. The results of the DPPH radical scavenging activities were shown in the Table 3 . The $\mathrm{IC}_{50}$ values $(50 \%$ inhibition concentration) was performed the highest activity from the leaf extract of $L$. indica $\left(\mathrm{IC}_{50}\right.$ of $\left.4.02 \mathrm{mg} / \mathrm{mL}\right)$, followed by stem $\left(\mathrm{IC}_{50}\right.$ of $\left.7.50 \mathrm{mg} / \mathrm{mL}\right)$, flower $\left(\mathrm{IC}_{50}\right.$ of $\left.16.94 \mathrm{mg} / \mathrm{mL}\right)$ and root $\left(\mathrm{IC}_{50}\right.$ of $\left.16.96 \mathrm{mg} / \mathrm{mL}\right)$ respectively. However, two antioxidants, ascorbic acid and butylated hydroxyanisole were used as the references in this study. The $\mathrm{IC}_{50}$ values of both ascorbic acid and butylated hydroxyanisole exhibited the strength inhibition $\left(\mathrm{IC}_{50}<0.1 \mathrm{mg} / \mathrm{mL}\right)$ in the DPPH assay.

Table 3. DPPH radical scavenging activities of the different organs extracts in Lactuca indica

\begin{tabular}{ccccccccc}
\hline & \multicolumn{7}{c}{ DPPH radical scavenging activity $(\%$ of control) } \\
\cline { 2 - 9 } Plant Part & \multicolumn{7}{c}{ Concentration $(\mathrm{mg} / \mathrm{mL})$} \\
\cline { 2 - 9 } & 0.1 & 0.25 & 0.5 & 1 & 2.5 & 5 & 10 & IC50 \\
\hline Root & $5.46 \pm 0.33 \mathrm{c}$ & $7.98 \pm 0.24 \mathrm{~b}$ & $8.90 \pm 0.27 \mathrm{c}$ & $12.23 \pm 0.31 \mathrm{~d}$ & $14.95 \pm 0.17 \mathrm{c}$ & $20.09 \pm 1.26 \mathrm{c}$ & $32.65 \pm 0.98 \mathrm{c}$ & 16.96 \\
Stem & $6.58 \pm 0.15 \mathrm{bc}$ & $9.49 \pm 0.28 \mathrm{a}$ & $11.45 \pm 0.41 \mathrm{~b}$ & $16.33 \pm 0.37 \mathrm{~b}$ & $21.23 \pm 0.30 \mathrm{~b}$ & $34.26 \pm 0.18 \mathrm{~b}$ & $64.23 \pm 0.68 \mathrm{~b}$ & 7.50 \\
Leaf & $9.09 \pm 0.40 \mathrm{a}$ & $10.30 \pm 0.26 \mathrm{a}$ & $16.36 \pm 0.31 \mathrm{a}$ & $29.76 \pm 0.39 \mathrm{a}$ & $47.24 \pm 1.00 \mathrm{a}$ & $72.40 \pm 0.71 \mathrm{a}$ & $90.37 \pm 0.15 \mathrm{a}$ & 4.02 \\
Flower & $7.52 \pm 0.55 \mathrm{~b}$ & $9.42 \pm 0.39 \mathrm{a}$ & $10.66 \pm 0.03 \mathrm{~b}$ & $13.65 \pm 0.15 \mathrm{c}$ & $15.67 \pm 0.28 \mathrm{c}$ & $21.81 \pm 0.59 \mathrm{c}$ & $32.54 \pm 0.79 \mathrm{c}$ & 16.94 \\
Ascorbic acid & $96.97 \pm 0.03$ & $97.22 \pm 0.03$ & $97.36 \pm 0.08$ & $97.49 \pm 0.03$ & $97.52 \pm 0.00$ & $97.55 \pm 0.03$ & $97.61 \pm 0.03$ & $<1$ \\
Butylated hydroxyanisole & $57.20 \pm 0.04$ & $88.92 \pm 0.03$ & $96.47 \pm 0.08$ & $97.35 \pm 0.03$ & $97.39 \pm 0.03$ & $97.55 \pm 0.03$ & $97.67 \pm 0.03$ & $<1$ \\
\hline
\end{tabular}

${ }^{\mathrm{Z}}$ Data represent the mean values $\pm \mathrm{SE}$ of three independent experiments. Means with the same letter in column are not significantly different at $\mathrm{p}<0.05$ level by Duncan's multiple range test. 
When cells were induced with various concentrations $(0.1,0.25,0.5,1,2.5,5$ and $10 \mathrm{mg} / \mathrm{mL})$ of methanol extracts, the DPPH radical scavenging activity was progressively increased in a dose-dependent manner. Methanol extracts at $10 \mu \mathrm{g} / \mathrm{mL}$ from leaf showed a pronounced radical scavenging activity $(90.37 \pm 0.15 \mathrm{mg} / \mathrm{mL})$ than those of methanol extract from stem $(64.23 \pm 0.68 \mathrm{mg} / \mathrm{mL})$, root $(32.65 \pm 0.98 \mathrm{mg} / \mathrm{mL})$ and flower extract $(32.54 \pm 0.79 \mathrm{mg} / \mathrm{mL}$ ) respectively (Table 3 ).

\subsection{ABTS Radical Scavenging Activity}

ABTS assays were performed in order to evaluate the radical scavenging activities of methanol extracts from various organs in Lactuca indica. The results of the ABTS radical scavenging activity were shown in Table 4. When the various organs of $L$. indica were treated with different concentrations $(1,2.5,5,10$ and $20 \mathrm{mg} / \mathrm{mL})$ of methanol extracts, the ABTS radical scavenging activity was progressively increased in a dose-dependent manner. However, methanol extracts at $20 \mathrm{mg} / \mathrm{mL}$ from leaf showed a manifested radical scavenging activity (99.84\%) compare to those of methanol extract from flower $(65.32 \pm 0.35 \%)$, root $(48.22 \pm 0.57 \%)$ and stem extract $(45.62 \pm 0.86 \%)$ respectively. The $\mathrm{IC}_{50}$ values $(50 \%$ inhibition concentration) was performed the highest activity from the leaf extract $\left(\mathrm{IC}_{50}\right.$ of $\left.6.70 \mathrm{mg} / \mathrm{mL}\right)$, followed by flower $\left(\mathrm{IC}_{50}\right.$ of $\left.13.69 \mathrm{mg} / \mathrm{mL}\right)$, root $\left(\mathrm{IC}_{50}\right.$ of $20.26 \mathrm{mg} / \mathrm{mL}$ ) and stem $\left(\mathrm{IC}_{50}\right.$ of $\left.21.07 \mathrm{mg} / \mathrm{mL}\right)$. However, two antioxidants, ascorbic acid and butylated hydroxyanisole were used as references in this study. The $\mathrm{IC}_{50}$ values of ascorbic acid and butylated hydroxyanisole exposed the high intensity of inhibition $\left(\mathrm{IC}_{50}<1 \mathrm{mg} / \mathrm{mL}\right)$ in the ABTS assay (Table 4).

Table 4. ABTS radical scavenging activities from different organs extracts in Lactuca indica

\begin{tabular}{ccccccc}
\hline & \multicolumn{7}{c}{ ABTS radical scavenging activity (\% of control) } \\
\cline { 2 - 7 } Plant Part & \multicolumn{5}{c}{ Concentration $(\mathrm{mg} / \mathrm{mL})$} \\
\cline { 2 - 7 } & 1 & 2.5 & 5 & 10 & 20 & IC50 \\
\hline Root & $4.44 \pm 0.19 \mathrm{~d}$ & $11.93 \pm 0.22 \mathrm{~d}$ & $17.22 \pm 0.09 \mathrm{c}$ & $31.28 \pm 2.43 \mathrm{c}$ & $48.22 \pm 0.57 \mathrm{c}$ & 20.26 \\
Stem & $6.59 \pm 0.17 \mathrm{c}$ & $14.53 \pm 0.18 \mathrm{c}$ & $18.08 \pm 0.38 \mathrm{c}$ & $29.65 \pm 0.04 \mathrm{c}$ & $45.62 \pm 0.86 \mathrm{~d}$ & 21.07 \\
Leaf & $14.31 \pm 0.15 \mathrm{a}$ & $25.88 \pm 0.34 \mathrm{a}$ & $44.52 \pm 0.51 \mathrm{a}$ & $87.25 \pm 0.11 \mathrm{a}$ & $99.84 \pm 0.02 \mathrm{a}$ & 6.70 \\
Flower & $12.32 \pm 0.19 \mathrm{~d}$ & $18.02 \pm 0.24 \mathrm{~b}$ & $27.08 \pm 0.19 \mathrm{~b}$ & $41.66 \pm 0.43 \mathrm{~b}$ & $65.32 \pm 0.35 \mathrm{~b}$ & 13.69 \\
Ascorbic acid & $98.43 \pm 0.00$ & $98.59 \pm 0.03$ & $98.53 \pm 0.00$ & $98.59 \pm 0.03$ & $98.45 \pm 0.03$ & $<1$ \\
Butylated hydroxyanisole & $98.09 \pm 0.00$ & $98.38 \pm 0.03$ & $98.23 \pm 0.00$ & $98.87 \pm 0.03$ & $98.66 \pm 0.03$ & $<1$
\end{tabular}

${ }^{\mathrm{z}}$ Data represent the mean values $\pm \mathrm{SE}$ of three independent experiments. Means with the same letter in column are not significantly different at $\mathrm{p}<0.05$ level by Duncan's multiple range test.

\subsection{Nitrite Scavenging Activity}

In order to investigate the nitrite scavenging activity of the various organs extracts in Lactuca indica, various acidic conditions were tested. The results of the nitrite scavenging activity were shown in table 5 . The nitrite scavenging activities were affected by the changes in $\mathrm{pH}$. The nitrite scavenging activity was decreased when the $\mathrm{pH}$ was changed from $\mathrm{pH} 1.2$ to $\mathrm{pH} 4.2$.

Table 5. Nitrite scavenging activities of the different organs extracts in Lactuca indica

\begin{tabular}{cccc}
\hline \multirow{2}{*}{ Plant Part } & \multicolumn{3}{c}{ Nitrite scavenging activity (\%) } \\
\cline { 2 - 4 } & $\mathrm{pH} 1.2$ & $\mathrm{pH} 4.2$ & $\mathrm{pH} 6.0$ \\
\hline Root & $55.63 \pm 1.90^{\mathrm{a}}$ & $49.85 \pm 2.03^{\mathrm{a}}$ & $\mathrm{ND}$ \\
Stem & $55.28 \pm 1.53^{\mathrm{a}}$ & $42.35 \pm 0.44^{\mathrm{b}}$ & $\mathrm{ND}$ \\
Leaf & $21.49 \pm 1.71^{\mathrm{b}}$ & $12.36 \pm 1.13^{\mathrm{c}}$ & $\mathrm{ND}$ \\
Flower & $21.25 \pm 0.92^{\mathrm{b}}$ & $10.33 \pm 0.81^{\mathrm{c}}$ & $\mathrm{ND}$
\end{tabular}

${ }^{\mathrm{z}}$ Data represent the mean values $\pm \mathrm{SE}$ of three independent experiments. Means with the same letter in column are not significantly different at $\mathrm{p}<0.05$ level by Duncan's multiple range test. N.D.: Not detected. 
However, the highest nitrite scavenging activity was exhibited from the methanol extract of root (55.63 \pm 1.90$)$, followed by stem $(55.28 \pm 1.53)$, leaf $(21.49 \pm 1.71)$ and flower $(21.25 \pm 0.92)$ at $\mathrm{pH} 1.2$. The fact that the nitrite scavenging activity was high at $\mathrm{pH} 1.2$ suggests that nitrosamine production can be inhibited in vivo (Table 5).

\section{Discussion}

In the last decade, medicinal plants with significant cytotoxic activity have played an important role in the development of cancer therapeutics (Al-Kalaldeh et al., 2010). Till now, more than 1000 plant species have identified which have attributed to show its potentiality in the field of anti-cancer research (Mukherjee et al., 2001). In the present study, the potential therapeutic properties; cytotoxicity, phenolic effects and antioxidants innate of Lactuca indica extracts were evaluated. Several molecular biological assays were performed with a view to investigate the bioactivities of plant extracts. In the case of cytotoxicity, a dose dependent inhibition of cell viability was found in all plant parts of Lactuca indica tested in this present study. The same results were found from another work that previously published (Chon et al., 2009). The methanol extract of Lactuca indica organs exhibited a promising cytotoxic activity against the human breast adenocarcinoma cell. On the other hand, the extracts were not cytotoxic at the tested concentration (up to $800 \mu \mathrm{g} / \mathrm{mL}$ ) towards HCT-116, SNU-1066 and HEK 293 cell lines which was partial similar with another report (Pittella et al., 2009). These results suggest a possible selectivity of the Lactuca indica extract against the human breast adenocarcinoma cell. The results also revealed that the higher methanol extracts concentration, the lower cell viability percentages. A recent report showed that at the highest concentration tested $(1 \mathrm{mg} / \mathrm{mL})$, the $\mathrm{IC}_{50}$ values could not determine that the specific extract showed a low cytotoxicity towards those tested cancer cell lines (Thetsrimuang et al., 2011).

All plants generate an amazing diversity of secondary metabolites from which phenolic compounds is one of the most important groups of these metabolites. However, in the present investigation, the highest content of total phenolics and flavonoids were observed from the leaf extracts and lowest from flower and root extracts of methanol respectively. These results suggest that the contents of total phenolics and flavonoids depend on organ to organ. In addition, previous results linked that total phenolics content depend on different species (Heo et al., 2007). They also observed that the total phenolic content of the studied vegetable extracts was correlated with the DPPH scavenging activity suggesting that total phenolics can play an authentic role in the antioxidant activity of plant material. So to say, the most of the naturally occurring phenolics retain antioxidants and anti-inflammatory innate that is thought to be availed their chemo-preventive activity (Wang et al., 2003). They also characterized that major phenolic constituents govern the candidate indexing compounds in the ctive EtOAc fraction of L. indica. In the present study, the methanol extracts of leaf contain a highly phenolic compounds $(35.09 \pm 0.15 \mathrm{mg} / \mathrm{g})$ suggesting that these compounds may play a crucial role in the observed antioxidant activity of $L$. indica.

During the last 3 decades, antioxidants based drugs have appeared in limelight for the prevention and treatment of fatal diseases like atherosclerosis, stroke, diabetes, Alzheimer's diseases, and cancer (Devasagayam et al., 2004). Herbs and spices along with medicinal plants especially Chinese medicinal plant extracts have been reported to proclaim antioxidant activity. However, for radical detoxification, mammalian cells perform efficient defense mechanisms distinctly (Farrukh et al., 2006). The main metabolic steps that are responsible for destroying peroxides are superoxide dismutase (SOD), catalase (CAT), and glutathione peroxidase (GPX). Moreover, the SOD is regarded as one of the most representative free radicals. Previous studied (Wang et al., 2003) revealed that SOD produces cell-damaging free radicals and oxidizing agents such as hydroxyl radicals which may have initial effects in the oxidation reactions.

Free radicals are thought to be one of the major factors in biological damages and DPPH has been applied to evaluate the free radical scavenging activity of natural antioxidants (Lee et al., 2004; Yokozawa et al., 1998; Zhu et al., 2001). In addition, DPPH regarded as a radical itself that possess a purple color. When DPPH reacts with antioxidants, it changes into a stable compound with a yellow color (Bondet et al., 1997). In the present evaluation, both the DPPH radical scavenging activity and ABTS radical scavenging activity has been increased with the higher concentration of methanol extract. Leaf extract of Lactuca indica exhibited the highest activity both ABTS radical scavenging activity and DPPH radical scavenging activity. All samples of Lactuca indica organ proved that DPPH radical scavenging activity were dose dependent. It also revealed that the methanol extracts from aerial parts of Korean salad plants showed a dose dependent DPPH radical scavenging activity (Heo et al., 2007). Free radical scavenging activity is also widely used mechanism for the determination of antioxidants which may affect to inhibit lipid peroxidation. To this end, antioxidants known as inhibitors of lipid peroxidation are very much essential both in food protection and the defense of living cells against oxidative damage (Barbaste et al., 2002). 
Nitric oxide (NO), produced by endothelial cells, macrophages, neurons that acts as an potential chemical mediator which are mainly involved in the regulation of various physiological processes and many types of disorders such as AIDS, cancer, alzheimer's and arthritis. In the present research, nitric scavenging activity was decreased with the increase of $\mathrm{pH}$ and was highest at a $\mathrm{pH}$ of 1.2. In our evaluation, the highest scavenging activity was found from the root extract of Lactuca indica. However, these results are similar to that previously reported by another (Kang et al., 1995). They also found that the nitrite scavenging activities in pine needle extract and mugwort extract were high at $\mathrm{pH}<3.0$ and was low at $\mathrm{pH} 6.0$.

We conclude that the Lactuca indica plants have high total phenolic contents and high antioxidant activity. Both the DPPH radical scavenging activity and ABTS scavenging activity fluctuates dose dependently and the phenolic content was significantly correlated with the free radical scavenging activity. The methanol extracts of Lactuca indica organs exposed an authentic cytotoxic activity against the human breast adenocarcinoma cell and root and leaf extract showed the weakest inhibition regarding $\mathrm{IC}_{50}$ value. However, these results suggest that the organ extract from Lactuca indica could be helpful for medicinal plants research community.

\section{Acknowledgements}

This study was supported by research fund from Chosun University, 2010.

\section{References}

Al-Kalaldeh, J. Z., Abu-Dahab, R., \& Afifi, F. U. (2010). Volatile oil composition and antiproliferative activity of Laurus nobilis, Origanum syriacum, Origanum vulgare, and Salvia triloba against human breast adenocarcinoma cells. Nutrition Research, 30(4), 271-278. http://dx.doi.org/10.1016/j.nutres.2010.04.001

Apel, K., \& Hirt, H. (2004). Reactive oxygen species: metabolism, oxidative stress, and signal transduction. Annu. Rev. Plant Biol., 55, 373-399. http://dx.doi.org/10.1146/annurev.arplant.55.031903.141701

Asada, K. (1994). Production and action of active oxygen species in photosynthetic tissues. In C. H. Foyer \& P. M. Mullineaux (Eds.), Causes of Photooxidative Stress and Amelioration of Defense Systems in Plants (pp. 77-104).

Barbaste, M., Berke, B., Dumas, M., Soulet, S., Delaunay, J. C., Castagnino, C., ... Vercauteren, J. (2002). Dietary antioxidants, peroxidation and cardiovascular risks. The Journal of Nutrition, Health \& Aging, 6(3), 209-223.

Basile, A., Ferrara, L., Pezzo, M. D., Mele, G., Sorbo, S., Bassi, P., \& Montesano, D. (2005). Antibacterial and antioxidant activities of ethanol extract from Paullinia cupana Mart. Journal of Ethnopharmacology, 102(1), 32-36. http://dx.doi.org/10.1016/j.jep.2005.05.038

Berridge, M. V., Herst, P. M., \& Tan, A. S. (2005). Tetrazolium dyes as tools in cell biology: new insights into their cellular reduction. Biotechnology Annual Review, 11, 127-152. http://dx.doi.org/10.1016/S1387-2656(05)11004-7

Bondet, V., Brand Williams, W., \& Berset, C. (1997). Kinetics and Mechanisms of Antioxidant Activity using the DPPH. Free Radical Method. LWT-Food Science and Technology, 30(6), 609-615. http://dx.doi.org/10.1006/fstl.1997.0240

Brand Williams, W., Cuvelier, M., \& Berset, C. (1995). Use of a free radical method to evaluate antioxidant $\begin{array}{llll}\text { activity. } \quad \text { LWT-Food } & \text { Science and }\end{array}$ http://dx.doi.org/10.1016/S0023-6438(95)80008-5

Cartea, M. E., Francisco, M., Soengas, P., \& Velasco, P. (2010). Phenolic compounds in Brassica vegetables. Molecules, 16(1), 251-280. http://dx.doi.org/10.3390/molecules16010251

Chen, G. X., \& Asada, K. (1989). Ascorbate peroxidase in tea leaves: occurrence of two isozymes and the differences in their enzymatic and molecular properties. Plant and Cell Physiology, 30(7), 987-998.

Chon, S. U., Heo, B. G., Park, Y. S., Kim, D. K., \& Gorinstein, S. (2009). Total phenolics level, antioxidant activities and cytotoxicity of young sprouts of some traditional Korean salad plants. Plant Foods for Human Nutrition, 64(1), 25-31. http://dx.doi.org/ 10.1007/s11130-008-0092-x

Devasagayam, T., Tilak, J., Boloor, K., Sane, K., Ghaskadbi, S. S., \& Lele, R. (2004). Free radicals and antioxidants in human health: current status and future prospects. Japi, 52, 794-804.

Dionisio Sese, M. L., \& Tobita, S. (1998). Antioxidant responses of rice seedlings to salinity stress. Plant Science, 135(1), 1-9. http://dx.doi.org/10.1016/S0168-9452(98)00025-9 
Egley, G., Paul Jr, R., Vaughn, K., \& Duke, S. (1983). Role of peroxidase in the development of water-impermeable seed coats in Sida spinosa L. Planta, 157(3), 224-232.

Farrukh, A., Iqbal, A., \& Zafar, M. (2006). Antioxidant and free radical scavenging properties of twelve traditionally used Indian medicinal plants. Turk J. Biol., 30, 177-183.

Hansen, M. B., Nielsen, S. E., \& Berg, K. (1989). Re-examination and further development of a precise and rapid dye method for measuring cell growth/cell kill. Journal of Immunological Methods, 119(2), 203-210. http://dx.doi.org/10.1016/0022-1759(89)90397-9

Heo, B. G., Park, Y. S., Chon, S. U., Lee, S. Y., Cho, J. Y., \& Gorinstein, S. (2007). Antioxidant activity and cytotoxicity of methanol extracts from aerial parts of Korean salad plants. BioFactors, 30(2), 79-89.

Kandpal, R. P., Vaidyanathan, C., Kumar, M. U., Sastry, K. K., \& Rao, N. A. (1981). Alterations in the activities of the enzymes of proline metabolism in Ragi (Eleusine coracana) leaves during water stress. Journal of biosciences, 3(4), 361-370.

Kang, H. M., \& Saltveit, M. E. (2002). Chilling tolerance of maize, cucumber and rice seedling leaves and roots are differentially affected by salicylic acid. Physiologia Plantarum, 115(4), 571-576.

Kang, Y. H., Park, Y. K., Oh, S. R., \& Moon, K. D. (1995). Studies on the physiological functionality of pine needle and mugwort extracts. Korean J. Food Sci. Technol., 27, 978-984. http://dx.doi.org/10.1034/j.1399-3054.2002.1150411.x

Kato, H., Lee, I. E., Chuyen, N. V., Kim, S. B., \& Hayase, F. (1987). Inhibition of nitrosamine formation by nondialyzable melanoidins. Agricultural and Biological Chemistry, 51(5), 1333-1338. http://dx.doi.org/10.1271/bbb1961.51.1333

Lee, J. Y., Hwang, W. I., \& Lim, S. T. (2004). Antioxidant and anticancer activities of organic extracts from Platycodon grandiflorum A. De Candolle roots. Journal of Ethnopharmacology, 93(2), 409-415. http://dx.doi.org/10.1016/j.jep.2004.04.017

Mishra, N. P., Mishra, R. K., \& Singhal, G. S. (1993). Changes in the activities of anti-oxidant enzymes during exposure of intact wheat leaves to strong visible light at different temperatures in the presence of protein synthesis inhibitors. Plant Physiology, 102(3), 903-910. http://dx.doi.org/10.1104/pp.102.3.903

Mittler, R. (2002). Oxidative stress, antioxidants and stress tolerance. Trends in Plant Science, 7(9), 405-410. http://dx.doi.org/10.1016/S1360-1385(02)02312-9

Moftah, A. E., \& Michel, B. E. (1987). The effect of sodium chloride on solute potential and proline accumulation in soybean leaves. Plant Physiology, 83(2), 238-240. http://dx.doi.org/10.1104/pp.83.2.238

Mukherjee, A. K., Basu, S., Sarkar, N., \& Ghosh, A. C. (2001). Advances in cancer therapy with plant based natural products. Current Medicinal Chemistry, 8(12), 1467-1486. http://dx.doi.org/10.2174/0929867013372094

Pittella, F., Dutra, R. C., Junior, D. D., Lopes, M. T., \& Barbosa, N. R. (2009). Antioxidant and cytotoxic activities of Centella asiatica (L) Urb. International Journal of Molecular Sciences, 10(9), 3713-3721. http://dx.doi.org/10.3390/ijms 10093713

Re, R., Pellegrini, N., Proteggente, A., Pannala, A., Yang, M., \& Rice-Evans, C. (1999). Antioxidant activity applying an improved ABTS radical cation decolorization assay. Free Radical Biology and Medicine, 26(9), 1231-1237. http://dx.doi.org/ 10.1016/S0891-5849(98)00315-3

Shah, R., Kathad, H., Sheth, R., \& Sheth, N. (2010). In vitro antioxidant activity of roots of Tephrosia purpurea linn. International Journal of Pharmacy \& Pharmaceutical Sciences, 2(3).

Singleton, V., \& Rossi, J. A. (1965). Colorimetry of total phenolics with phosphomolybdic-phosphotungstic acid reagents. American journal of Enology and Viticulture, 16(3), 144-158.

Thetsrimuang, C., Khammuang, S., Chiablaem, K., Srisomsap, C., \& Sarnthima, R. (2011). Antioxidant properties and cytotoxicity of crude polysaccharides from Lentinus polychrous Lév. Food Chemistry, 128(3), 634-639. http://dx.doi.org/ 10.1016/j.foodchem.2011.03.077

Wang, S. Y., Chang, H. N., Lin, K. T., Lo, C. P., Yang, N. S., \& Shyur, L. F. (2003). Antioxidant properties and phytochemical characteristics of extracts from Lactuca indica. Journal of Agricultural and Food Chemistry, 51(5), 1506-1512. http://dx.doi.org/10.1021/jf0259415

Wojtaszek, P. A. (1997). Oxidative burst: an early plant response to pathogen infection. Biochem. J., 322, 
681-692.

Yokozawa, T., Chen, C. P., Dong, E., Tanaka, T., Nonaka, G. I., \& Nishioka, I. (1998). Study on the inhibitory effect of tannins and flavonoids against the 1, 1-diphenyl-2-picrylhydrazyl radical. Biochemical Pharmacology, 56(2), 213-222. http://dx.doi.org/10.1016/S0006-2952(98)00128-2

Zhishen, J., Mengcheng, T., \& Jianming, W. (1999). The determination of flavonoid contents in mulberry and their scavenging effects on superoxide radicals. Food Chemistry, 64(4), 555-559. http://dx.doi.org/10.1016/S0308-8146(98)00102-2

Zhou, B., Guo, Z., \& Liu, Z. (2005). Effects of Abscisic Acid on Antioxidant Systems of (Aublet) Sw. under Chilling Stress. Crop Science, 45(2), 599-605. http://dx.doi.org/doi:10.2135/cropsci2005.0599

Zhu, N., Wang, M., Wei, G. J., Lin, J. K., Yang, C. S., \& Ho, C. T. (2001). Identification of reaction products of (-)-epigallocatechin,(-)-epigallocatechin gallate and pyrogallol with 2, 2-diphenyl-1-picrylhydrazyl radical. Food Chemistry, 73(3), 345-349. http://dx.doi.org/10.1016/S0308-8146(00)00308-3

\section{Copyrights}

Copyright for this article is retained by the author(s), with first publication rights granted to the journal.

This is an open-access article distributed under the terms and conditions of the Creative Commons Attribution license (http://creativecommons.org/licenses/by/3.0/). 